\title{
NUTRITIONAL EDEMA IN THE DOG. V. DEVELOPMENT OF DEFICITS IN ERYTHROCYTES AND HEMOGLOBIN ON A DIET DEFICIENT IN PROTEIN ${ }^{1}$
}

\author{
By A. A. WEECH, M. WOLlSTEIN and E. GOETTSCH \\ (From the Department of Diseases of Children of Columbia University, College of Physicians \\ and Surgeons, New York)
}

(Received for publication March 22, 1937)

In a previous report from this laboratory (1), it was shown that maintenance of dogs on a diet deficient in protein is accompanied by a progressive fall in the concentration of albumin in the serum. Average globulin concentration is virtually unaffected, the decline in albumin being paralleled by a similar decrease in total protein. Studies of nitrogen balance in five animals indicated that the loss of albumin from the serum can account for only 3 or 4 per cent of the total loss of nitrogen from the body. It is reasonable then to inquire what other tissues contribute to the total loss and to what degree. Although a complete answer to this question cannot be given, it has been possible to assemble data which bear on the fate of hemoglobin during maintenance on the diet. Along with the serum albumin, the hemoglobin also suffers depletion; from the quantitative aspect of contribution to the total loss of nitrogen the depletion of hemoglobin is more important than the loss in albumin. The data which lead to this conclusion form the basis of the present report.

\section{METHODS}

Animals. Young adult dogs of mongrel breeds weighing between 15 and 25 kilos were selected on the basis of health, vigor and willingness to eat the special diet.

Diet. The composition of the low protein diet has been described previously (1); a discussion of the adequacy of the diet from the standpoint of vitamins has also been given (2). From the viewpoint of this paper which is concerned chiefly with hemoglobin it may be noted that, in a control experiment in which 90 grams of the sugar was replaced by an equal amount of casein, there was

1 The results of this investigation were presented in less complete form at the meeting of the American Pediatric Society, Bolton Landing, New York, June 13, 1936 (Am. J. Dis. Child., 1936, 52, 1280). no change in relative red cell volume (hematocrit) or in serum protein over a period of 77 days. On the average, the diet as offered furnished $2.4 \mathrm{mgm}$. of iron per kilo per day; however, after 6 to 8 weeks the intake of iron was usually less because of refusals. As a further control in another experiment the low protein diet was supplemented by the addition of 11 grams of liver extract ${ }^{2}$ daily. The changes in this experiment were identical with those in other experiments in which the supplement was not given. It is fair then to assume that the findings to be reported resulted from protein deficiency alone.

Blood volume. Plasma volume was estimated by one or another modification of the "dye method" (3). Red cell volume and total blood volume were calculated from the plasma volume by means of hematocrit readings. In most experiments vital red was injected; recently we have used, and now prefer, the blue dye ( $\mathrm{T}-1824$, Eastman Kodak Company) described by Gregersen, Gibson and Stead (4). In our early work dye concentration was measured in the Hilger spectrophotometer as described by Graff and Clarke (5) ; this method permits separate identification of the color due to dye, of the natural color of the plasma, and of extraneous color arising through hemolysis. The method consumes much time and in our hands has not brought increased accuracy over that obtainable in a colorimeter when certain precautions are observed. The first precaution is that the technic of blood sampling be such that hemolysis of red cells is

2 The liver extract was Liver Extract Number 343 furnished through the kindness of Eli Lilly and Company. Cod liver oil was given in all diets in the form of Cod Liver Oil Stearine contributed by Mead Johnson and Company. In a few experiments the diet was supplemented by the addition of a concentrate of rice polishings known by the trade name of Ryzamin-B and donated by Burroughs Wellcome and Company. 
avoided or reduced to a very slight amount. Frequent examination of plasma in a Bausch and Lomb spectrometer has demonstrated the feasibility of obtaining a majority of samples without contamination by hemoglobin. When slight hemolysis has occurred and the blue dye, T-1824, is being used it is possible to eliminate that portion of the spectrum in which the absorption of light by hemoglobin is strongest by using a red filter, Wratten No. 72, in the colorimeter. The second precaution is that the known and unknown mixtures of dye and plasma which are to be compared in the colorimeter should match as closely as possible. Te secure close matching it is frequently necessary to prepare a second standard after the result of comparing the first with the unknown mixture has been obtained. In general, the necessity for close agreement between the two mixtures increases in proportion to the intensity of natural plasma color. The colorimeter comparison is made with the purpose of ascertaining the factor which relates concentration of dye in the unknown mixture $a$ to concentration of dye in the known mixture $b$-that is, one seeks for the ratio of $a$ to $b$. Actually since both mixtures contain an equal amount of plasma, the natural color $c$ of which is variable, the colorimeter gives the ratio of $a+c$ to $b+c$. It is clear that this latter ratio approaches the value of the desired ratio under two conditions, namely, when natural color $c$ is very small and when the two solutions nearly match so that both ratios approach unity. Dye injections were made into the jugular vein; samples for analysis were withdrawn from the femoral artery and mixed under oil with a measured amount of 1.4 per cent solution of sodium oxalate. The amount of blood in the mixture was determined by weighing. This part of the procedure was the same as that described by Graff and Clarke (5); the technic of these authors was also followed in making the hematocrit estimations.

The determination of plasma volume and blood volume is admittedly not a precise analytic procedure; the exact error is not known. In order to minimize the influence of the error the average of findings in a number of experiments will be reported rather than the measurements on single animals. The significance of such averages can be established by statistical methods even though the error of single measurements is unknown.

\section{REPRESENTATIVE PROTOCOL}

The data upon which this report is based represent serial observations in 81 experiments performed on 38 dogs. The duration of the experiments was from 21 to 108 days. Approximately 140 measurements of blood volume were utilized in calculating the average values which are to be given. Since so much observational data cannot be presented in detailed form, the following single protocol is offered as representative of the longer type of experiment from which the data were assembled.

Dog 5-69, a male of police type, aged about 1 year, was placed on the basal low protein diet supplemented by the addition of 90 grams of casein daily on March 4, 1935. The diet was well taken and resulted in a rapid gain of 3 kilos; the feeding of casein was continued until the weight had been stationary for 8 days. On April 1 (first experimental day) the casein was removed from the diet and the period of low protein feeding commenced at a level of 75 calories per kilo of weight per day. The basal diet was supplemented by the daily addition of 0.4 gram of a concentrate of rice polishings and of 11.0 grams of liver extract. There were no refusals until the 53d experimental day. At this time the appetite began to fail; on the 65th day the diet was reduced to onehalf the original quantity although the supplements were continued in the original amounts. This level of feeding was maintained throughout the remainder of the experiment; because of anorexia the diet often had to be fed forcibly. Edema first appeared over the dorsa of the hind feet on the 59th day. During the next 10 days the edema increased in amount and extended to involve all four legs. Thereafter it fluctuated in amount but gradually became massive in the hind legs. Ascites did not develop and the edema of the forelegs was always moderate. The animal was sacrificed on the 101st day by injecting ether into the heart. During the experiment the following measurements were made:

Albumin per $100 \mathrm{cc}$. serum: 1st day, 3.39 grams; 22d day, 2.65 grams; 43d day, 2.20 grams; 60th day, 1.66 grams; 64th day, 1.58 grams; $72 \mathrm{~d}$ day, 1.54 grams; 87 th day, 1.24 grams.

Relative red cell volume: 1st day, 42.3 per cent; $22 \mathrm{~d}$ day, 45.1 per cent; 43d day, 41.8 per cent; 47th day, 41.0 per cent; 68 th day, 34.7 per cent; $72 \mathrm{~d}$ day, 32.6 per cent; 89th day, 32.2 per cent.

Erythrocytes per cubic millimeter of blood: 1st day, 5.38 million; 29 th day, 6.33 million; 50 th day, 5.56 million; 68th day, 4.62 million; 80th day, 5.10 million; 87 th day, 5.13 million.

Hemoglobin per $100 \mathrm{cc}$. blood: 1st day, 14.5 grams; 29th day, 17.0 grams; 50th day, 14.5 grams; 68th day, 11.6 grams; 80th day, 12.2 grams; 87th day, 10.9 grams.

Plasma volume : 1st day, $744 \mathrm{cc}$; 22d day, 636 cc.; 43d day, 676 cc. ; 72d day, 687 cc. 
Erythrocyte volume : 1st day, 546 cc.; $22 \mathrm{~d}$ day, 522 cc. ; 43d day, 486 cc.; $72 d$ day, 331 cc.

Body weight (actually determined daily) : 1st day, 16.2 kilos; 20th day, 15.0 kilos; 40 th day, 14.5 kilos; 60th day, 14.0 kilos; 80th day, 12.6 kilos; 100th day, 11.6 kilos.

\section{EXPERIMENTAL OBSERVATIONS}

Effect of the low protein diet on relative red cell volume and hemoglobin. Direct measurement of hemoglobin has not been a routine procedure in the conduct of these experiments ; however, measurements of relative red cell volume in hematocrit tubes have been made regularly. There are 21 protocols with sufficient data to permit following the course of this measurement through a period of 80 to 90 days on the diet. The findings are presented in Figure 1 in the form of an average the final value at the end of 3 months is as high as it is, namely, 72 per cent of the initial level.

Since there is no obligatory parallelism between relative red cell volume and hemoglobin, four animals were selected for a more intensive study in which erythrocyte counts, hemoglobin determinations, and hematocrit readings were made at regular intervals during maintenance on the diet. From the data obtained the value for each of the three measurements at 10-day intervals was determined by interpolation; the resulting values for each of the 4 dogs were averaged; these average figures were finally expressed as percentages of the mean level during the entire experiment. This method of expressing the results permits one to chart the three measurements on the same scale

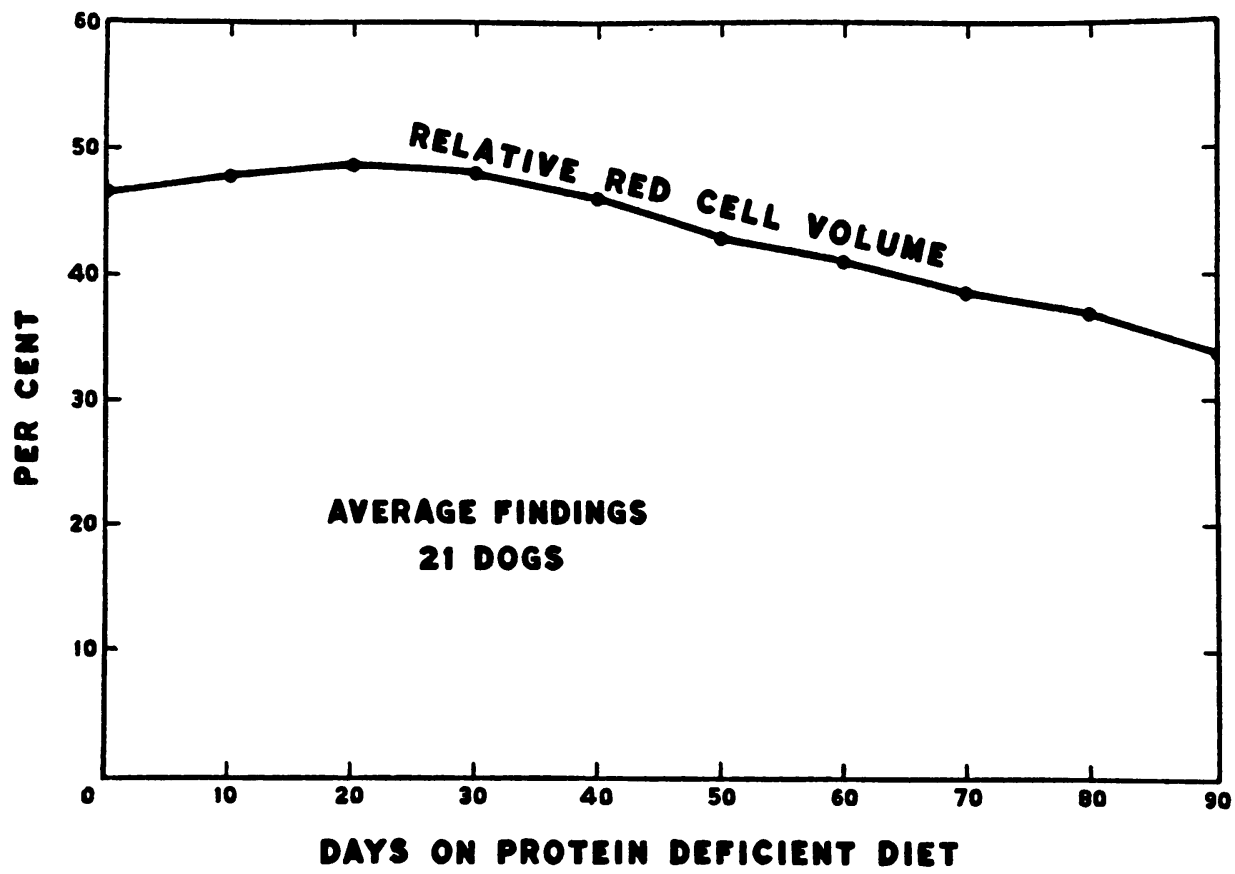

Fig. 1. The Average Result of Hematocrit Readings in 21 Dogs during Maintenance on the Low Protein Diet

curve for the 21 animals. The average relative red cell volume increases during the first 20 to 30 days of maintenance on the diet and thereafter declines gradually but progressively. The initial value is 46.6 per cent cells; the last value recorded after 90 days on the diet is 33.7 per cent cells. The conclusion is warranted that maintenance on the diet eventually leads to a decrease in relative red cell volume but it is interesting that so that changes in one measurement which are exactly proportional to changes in another will produce identical lines on the chart. Figure 2 presents the findings with these animals. The three curves representing hematocrit, hemoglobin and number of erythrocytes, although not identical, do follow the same trend with sufficient closeness to make it clear that variations in relative red cell volume in these experiments provide a satis- 


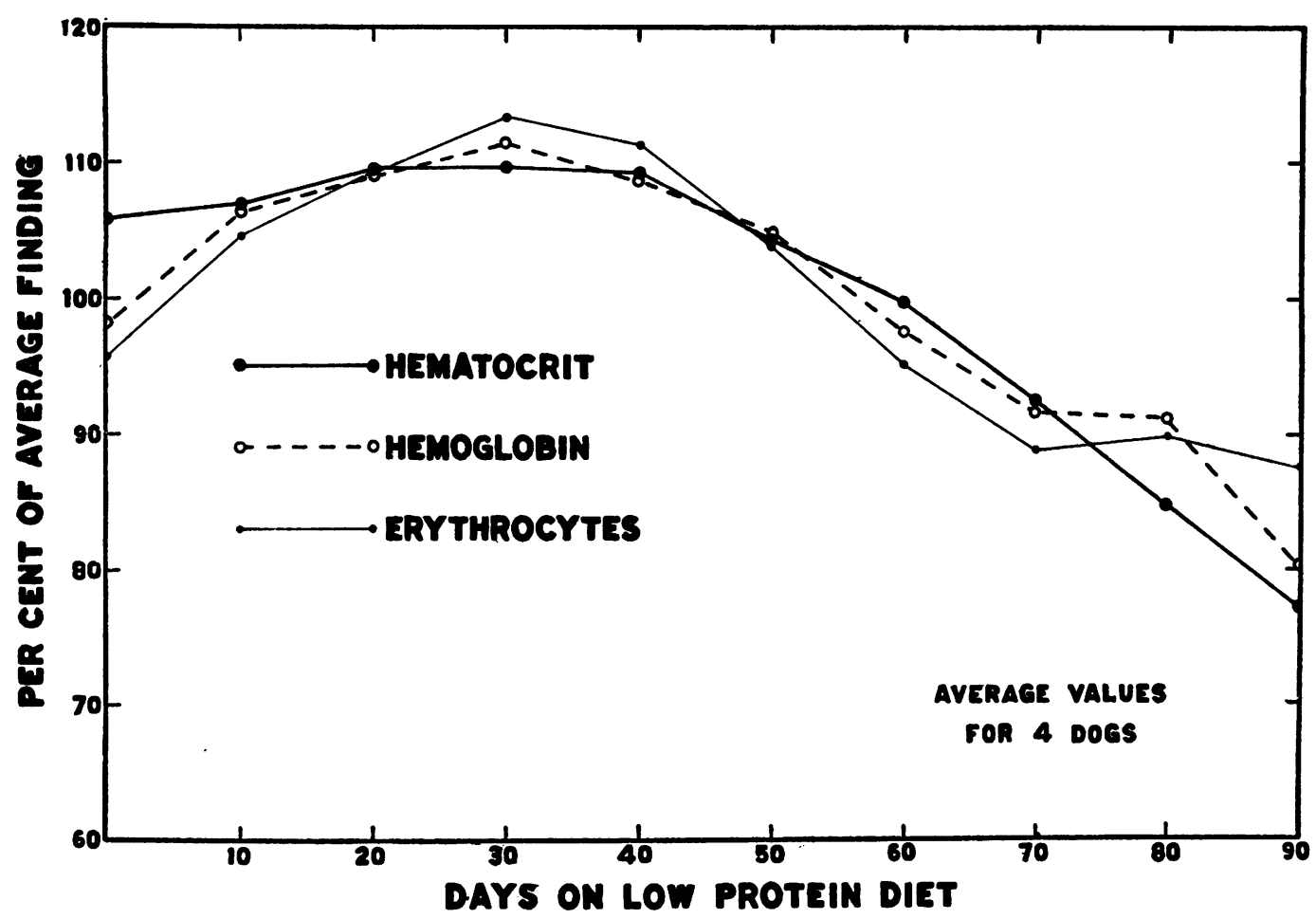

Fig. 2. Relative Variations in Per Cent Cell Volume, Hemoglobin Concentration and Number of Erythrocytes in 4 Dogs during Maintenance on the Low Protein Diet

factory measure of associated variations in hemoglobin and red cell count. This conclusion is supported by the failure to observe consistent changes in the color index during the experiments. The three curves in Figure 2 follow the same general course as the line in Figure 1, that is, there is an initial rise which reaches a peak in about 30 days and thereafter a progressive fall.

Effect of the low protein diet on the volume of plasma and red cells in the circulation. An explanation of the initial rise in hemoglobin as well as a better measure of the final depletion are forthcoming when one examines data obtained in measurements of blood volume. The average findings with ten dogs are presented in Figure 3. The total volume of circulating erythrocytes declines progressively during maintenance on the diet; there is no initial rise and the final volume which is reached after 80 days is about half ( 53 per cent) of the initial. Extended to 90 days by extrapolation, for comparison with Figure 1, the data permit an estimate of about 46 per cent of the total red cells remaining in the circulation for this length of time; the estimate from Figure 1 which was based solely on concentration of red cells was 72 per cent and was far from the true degree of hemoglobin depletion. Figure 3 also records a progressive decline in total blood volume during maintenance on the diet. However, the plasma volume decreases during the initial 20 to 30 days only; thereafter, it is maintained at an approximately constant value. Because the early decline in plasma volume takes place at a more rapid rate than the decrease in cell volume it follows that the concentration of red cells must rise during this period. The data therefore offer an explanation for the early increase in concentration of red cells and hemoglobin which was shown in Figures 1 and 2.

That deficits in serum albumin are associated with diminished volume of the plasma has been established by Darrow and Buckman (6) for children with nephrosis, by Chang (7) for humans with nutritional edema, by Lepore (8) for hypoproteinemic dogs, and by others. The results in these experiments are therefore in agreement with data recorded elsewhere. The fact that the plasma volume does not continue to fall 
after 20 to 30 days on the diet does not mean that at this stage it is no longer sensitive to changes in albumin concentration. At any stage of serum albumin depletion an immediate rise in plasma volume will occur if the albumin concentration is raised by transfusions with serum (9). The by the serum protein concentration only insofar as the cell volume is constant."

Depletion of hemoglobin during the early stages of maintenance on the low protein diet. From Figure 3 it is seen that the diminution in volume of red cells and therefore in hemoglobin appears

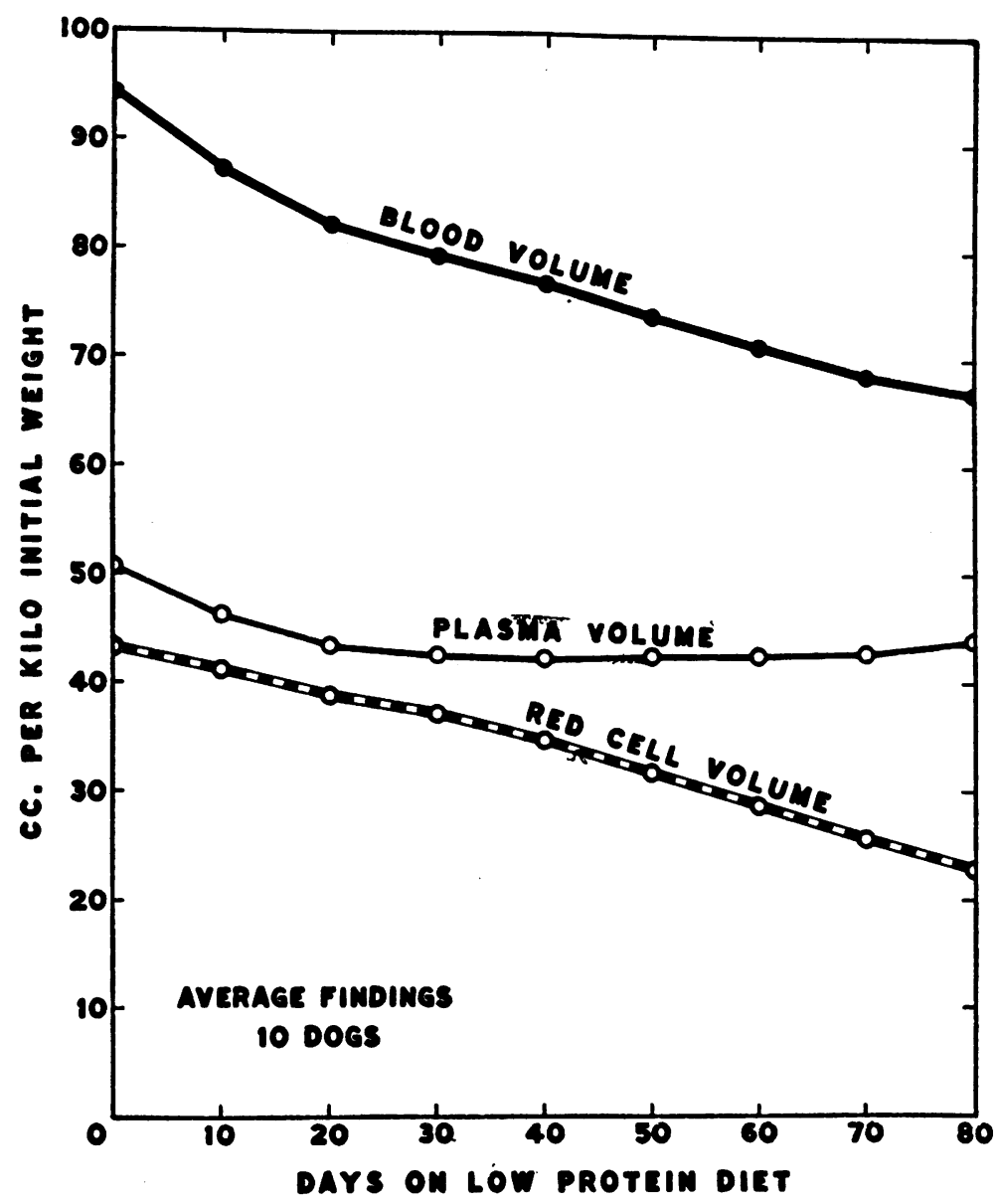

Fig. 3. Changes in Blood Volume, Plasma Volume and Red Cell Volume during Maintenance on the Low Protein Diet

maintenance of plasma volume at a constant level during the later stages can only mean that another limiting factor has come into play, namely, the total blood volume. Since the loss of red cells appears to go on relentlessly it is perhaps not surprising that further reductions in blood volume should be opposed by a force strong enough to compensate for the effect on plasma volume of increasing albumin depletion. Melnick and Cowgill (10) have observed an identical phenomenon in dogs subjected to plasmapheresis; they state that "the plasma volume appears to be regulated to begin at once when the dietary protein is insufficient. Because this circumstance implies the absence of a reserve store of hemoglobin in the body, it is worth while to establish the existence of an early change by rigid statistical methods. Observations in 60 experiments are available for this purpose. With these animals measurements were made initially and again after 3 weeks on the diet. The average findings shown in Table $I$ are in agreement with the corresponding portion of the curves in Figures 1,2 and 3. During the 3 weeks there is a rise in relative red cell volume and a fall 
TABLE I

Average change in the blood of 60 dogs after maintenance for 3 weeks on the low protein diet. Average weight of the dogs $=19.3$ kilos

\begin{tabular}{|c|c|c|c|c|}
\hline & \multirow{2}{*}{ Hematocrit } & \multicolumn{3}{|c|}{ Total circulating volume } \\
\hline & & Plasma & Red cells & Blood \\
\hline $\begin{array}{l}\text { Initial . . . . . . } \ldots \ldots \ldots \\
\text { 3 weeks. . } \ldots \ldots \ldots \ldots \ldots \\
\text { Change } \ldots \ldots \ldots \ldots \ldots\end{array}$ & $\begin{array}{c}\text { per cent } \\
47.5 \\
49.4 \\
1.9\end{array}$ & $\begin{array}{l}c c . \\
935 \\
817 \\
118\end{array}$ & $\begin{array}{r}c c . \\
859 \\
811 \\
48\end{array}$ & $\begin{aligned} c c \\
1793 \\
1628 \\
165\end{aligned}$ \\
\hline
\end{tabular}

in plasma volume, in red cell volume and in total blood volume. The average decrease in red cells is $47.6 \mathrm{cc}$. or 5.5 per cent of the average initial cell volume. The decrease of $47.6 \mathrm{cc}$. possesses a probable error of $\pm 6.25 \mathrm{cc}$; the ratio of the decrease to its probable error is 7.6 and indicates that the probability of a decrease being due to errors of sampling and measurement is less than one in a million.

Depletion of hemoglobin then is clearly demonstrable in as short a time as 3 weeks when the dietary protein is inadequate. Indeed, there is no evidence in the experiments that the depletion does not begin at once, that is, there is no evidence of a reserve supply either of hemoglobin or of precursors of hemoglobin which are being utilized to maintain a constant amount in the circulation. If such reserves are called upon their effect must be offset by other factors within a very few days. This finding has at least theoretical interest since Whipple and his collaborators (11) have demonstrated clearly that the body does contain a reserve supply of hemoglobin-building material which can be mobilized to assist in recovery from the anemia which follows hemorrhage. In the present experiments the failure of normal hemoglobin production is probably not concerned with the chromogenic iron-containing portion of the hemoglobin molecule; it probably results from insufficiency of the protein, globin. Presumably all of the body proteins, and among them globin, are affected by the faulty diet. Moreover, it would seem that the reserve stores of protein, which under acute stress are capable of yielding new hemoglobin, are gradually depleted along with the globin and other body proteins. Thus one observes no evidence of reserve hemoglobin material in experiments of this type. The point is worthy of emphasis because the experimental conditions are such as must often be duplicated in the clinic.

Relative aspects of the depletion of the circulating proteins. By combining the data from a previous article (1) concerning the fall in concentration of albumin and globulin in the serum during maintenance on the diet with the findings in this investigation of the changes in the circulating volumes of plasma and of red cells, it is possible to determine the relative extent to which the several circulating proteins are depleted. The result of such a calculation is presented in Figure 4. The albumin of the serum suffers the greatest percentage depletion; after 80 days only 30 per cent of the original amount remains in the circulation. With hemoglobin, about 50 per cent remains. The losses contrast sharply with the slight degree to which the serum globulin is affected; 90 per cent of the initial supply is still circulating at the end of the same period. Figure 4 also shows the average percentage loss in body weight during the experiments. Although the meaning of this weight line is somewhat confused by the tendency toward edema formation, it is probably sufficient to show that the losses in hemoglobin and in serum albumin are greater, and the loss in serum globulin is less, than the loss in total body mass.

The percentage losses shown in Figure 4 do not indicate the actual quantities of the several proteins which are removed from the circulation. The distinction assumes importance from the circumstance that a healthy dog has in his circulation about nine times as much hemoglobin as serum albumin. The 50 per cent loss of hemoglobin therefore refers to a much larger amount of protein than the 70 per cent loss of albumin. From the data obtained in the experiments in which simultaneous measurements of relative red cell volume and hemoglobin were carried out, it is estimated that the average initial level of hemoglobin in the ten dogs of the blood volume series was 15.3 grams per $100 \mathrm{cc}$. of blood. The corresponding average for blood volume was $93 \mathrm{cc}$. per kilo and for body weight it was 16.7 kilos. From these data the average total circulating hemoglobin per dog can be computed; it was 237 grams. Since 47.2 per cent (from values in Figure 4) of this hemoglobin disappeared during a period of 80 days on the diet, the total loss in 
hemoglobin per dog is found to be 112 grams. In is shown graphically in Figure 5. Roughly onea similar way the loss in serum albumin is found to be 18.3 grams and the loss in serum globulin is 2.4 grams. fifth of the body protein which is catabolized by the dog during this period of insufficient protein intake is withdrawn from the circulation; the re-

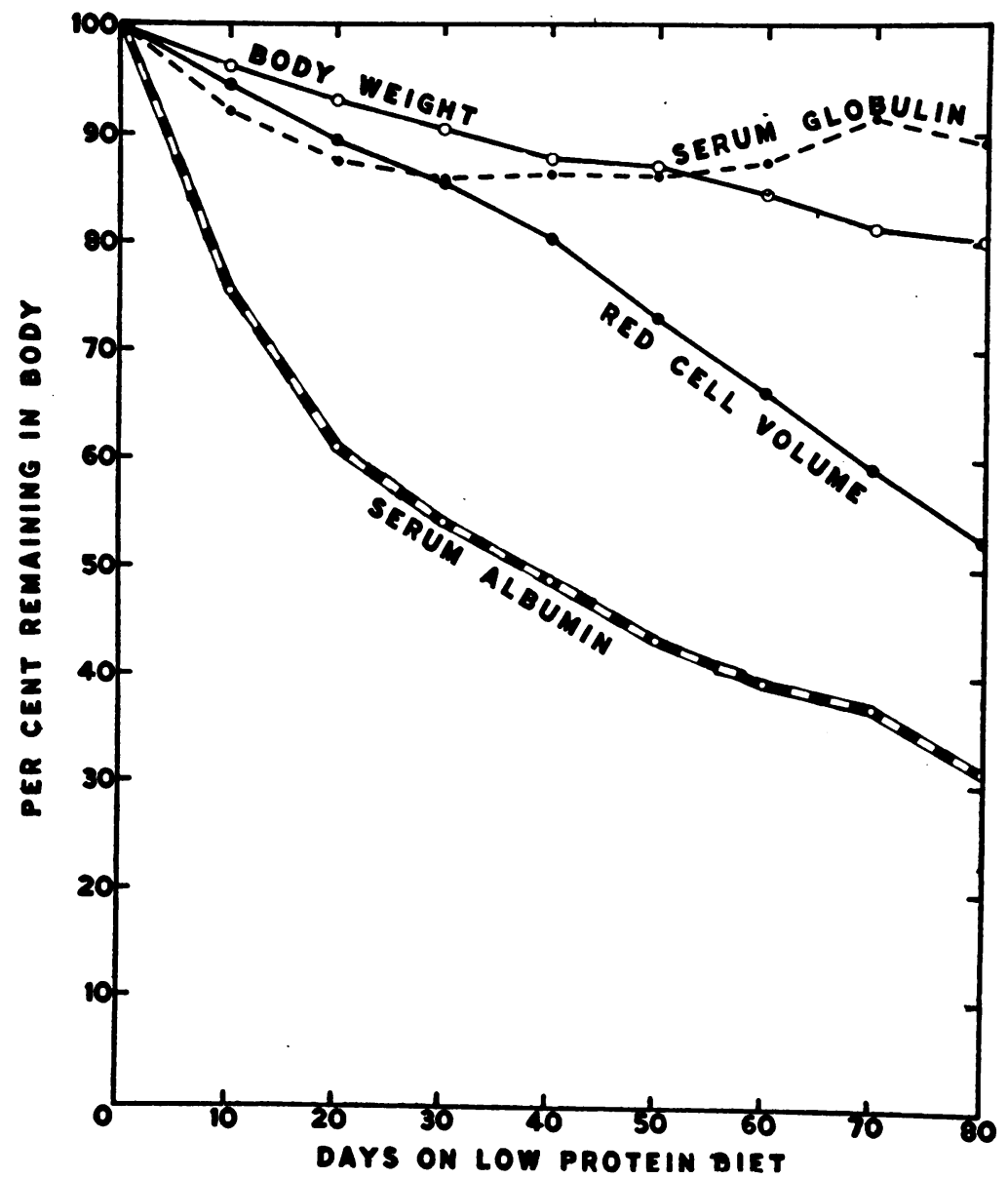

Fig. 4. Losses in the Circulating Proteins during Maintenance on the Diet Expressed as Percentages of the Original Amount RemainING AFTER VARIOUS TIME INTERVALS

The results of the preceding calculation are conveniently expressed in relation to an approximation of the total nitrogen loss from the body during the same period. From the results of studies of the nitrogen balance in another series of five dogs on the same diet (1), we have estimated an average daily loss of nitrogen of 1.2 grams for dogs whose weights correspond to those in the present series. This means a loss of protein of 7.5 grams per day or a total loss during 80 days of 600 grams of protein. The relationship between this approximation of the total loss of protein and the losses in circulating proteins maining four-fifths is contributed by tissues outside the circulation. Within the blood stream the relative contributions are: hemoglobin, 18.7 per cent ; albumin, 3.1 per cent ; globulin, 0.4 per cent. Moreover, the circumstance that the several circulating proteins are involved both relatively and absolutely to different extents in the process of protein catabolism suggests strongly that the proteins of organs and other body tissues are likewise involved to different degrees. This is in agreement with the recent experiments of Addis, Poo and Lew (12) who have shown with rats that during a seven-day fast the liver loses 40 per 
cent of its original protein, the kidneys and the blood 20 per cent each, the heart 18 per cent, the brain 5 per cent, and that there is no loss of protein from the eyes, the testicles or the adrenals. that the formation of erythrocytes and the production of hemoglobin are essentially independent physiological processes, then it must be admitted that these dogs do not build red cells in a normal

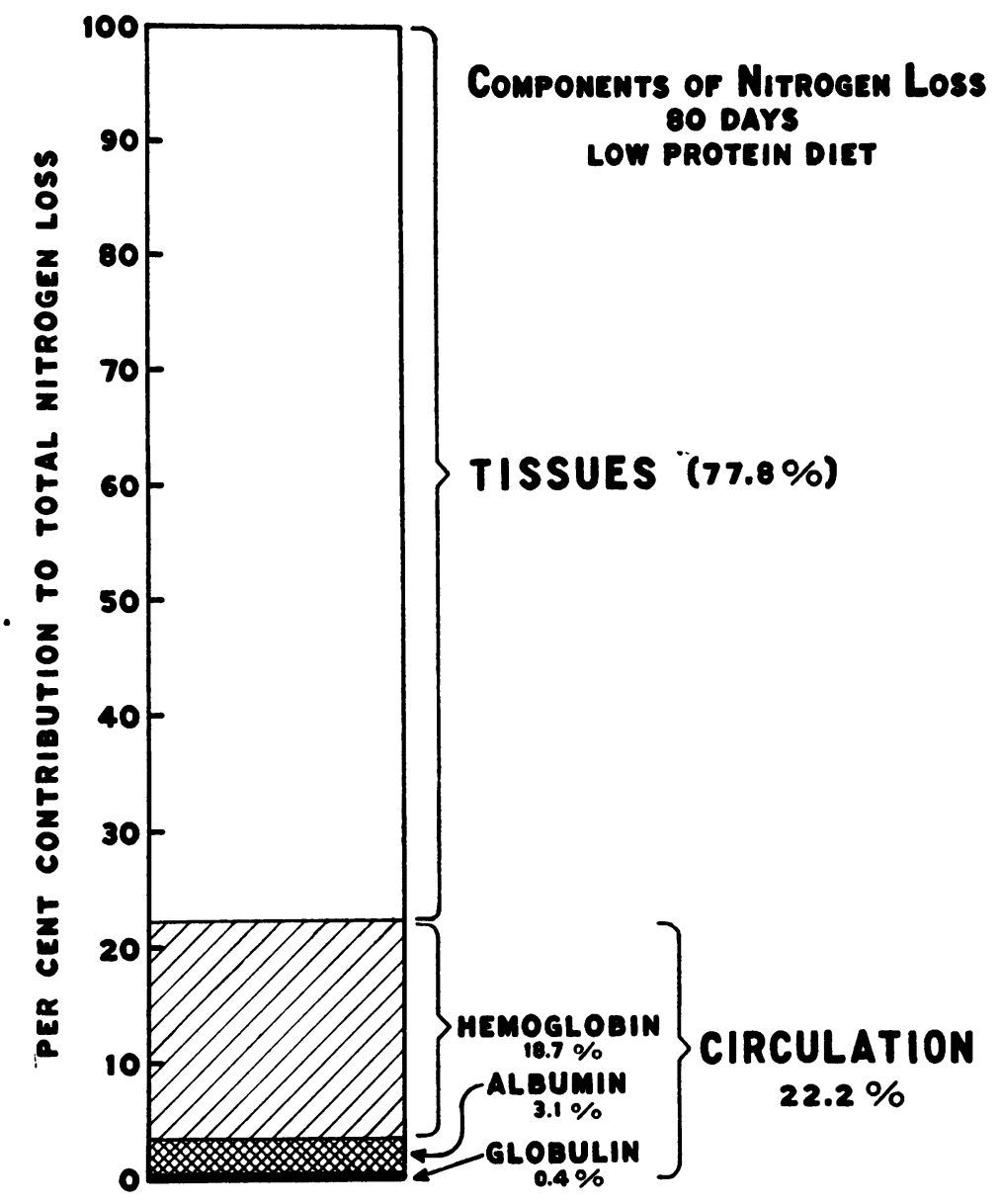

Fig. 5. Relationship between the Total Loss of Protein from the Body and the Losses in the Circulating Proteins after 80 Days on the Low Protein Diet

\section{COM MENT}

When the investigations reported in this paper were discussed at the meeting of the American Pediatric Society, Cooley (13) objected to interpreting the experiments as indicating defective formation of hemoglobin. Since, during maintenance on the low protein diet, the changes in the hemoglobin level parallel those of the erythrocyte count, Cooley thought there was an equal probability that the defect was one which concerned the structural material for cell building. This possibility cannot be denied. Indeed, if it is true way. If they did, one would expect to find a secondary anemia of the type which results from deprivation of iron, that is, an anemia with low hemoglobin, relatively high erythrocyte count, and low color index. However, the low protein diet is known to produce general depletion of the stores of protein in the body; for this reason it is difficult to believe that the depletion of hemoglobin is entirely secondary to an inability of the body to manufacture the structural material of cells. It is easier to think that the formation of both erythrocytes and hemoglobin is inhibited by 
the diet. The point which Cooley has raised is of considerable interest. It is not, however, concerned with the basic fact that dogs during maintenance on a low protein diet lose a large amount of hemoglobin and that this loss constitutes an appreciable portion of the total nitrogen which is removed from the body.

From the clinical standpoint this work has served to stress again the important relationship which exists between the total volume of the plasma and its albumin concentration. It further emphasizes the fact that the usual hemoglobin determination is liable to give a false picture of the total hemoglobin when the conditions are such that the plasma volume is changing. Many patients with illnesses of brief duration experience anorexia and as a result show a moderate depletion of albumin in the serum. With these patients the hemoglobin level is usually unaffected; with more protracted illness anemia is a Common sequel. In the light of this work it appears likely that this early maintenance of a normal concentration of hemoglobin in the blood should be interpreted not as an evidence of a "reserve store" of hemoglobin in the body but as an expected phenomenon when both erythrocytes and the volume of the plasma are decreasing at the same rate. In another group of patients it is sometimes necessary to interpret correctly the significance of a rapid fall in hemoglobin concentration at a time when the volume of the plasma is increasing rapidly. This phenomenon is encountered in the nutritional type of hypoalbuminemia; with the institution of high protein feeding the serum albumin and with it the plasma volume increase rapidly, and the hemoglobin declines. In one patient whom we were permitted to observe, the fall in hemoglobin was so marked, from 14.4 to 9.8 grams per $100 \mathrm{cc}$. blood after four weeks of high protein feeding, that her attending physician became alarmed and ordered a transfusion. With this patient the decline in the hemoglobin level was associated with a rise in the concentration of protein in the serum from 3.2 to 5.4 grams per cent; it is almost certain that the hemoglobinemia resulted from the increase in plasma volume which accompanies a rising albumin concentration and that it was not an evidence of disappearance of hemoglobin from the body.

\section{SUM MARY}

Dogs maintained on a diet deficient in protein exhibit in the blood an initial rise and later a progressive fall in relative red cell volume, in red cell count, and in hemoglobin concentration. Measurement of the total volume of red cells in the circulation shows that the decline in hemoglobin is continuous from the time of starting the diet. Measurement of the total amount of plasma in the circulation discloses an initial rapid fall to a volume which is then maintained for the duration of the experiment. Because the early decreases in circulating volumes affect both plasma and erythrocytes, the usual red cell counts and hemoglobin determinations fail to record the progressive loss from the circulation.

The decrease in volume of the red cells is demonstrable with statistical certainty after maintenance on the diet for as short a time as 3 weeks. This circumstance argues against the existence of a " reserve store" of hemoglobin-building material which can be utilized to maintain a constant level of hemoglobin in the blood. Since such a reserve is clearly demonstrable when the hemoglobin is depleted by hemorrhage, it appears that not only the circulating hemoglobin but also the reserve stores are depleted by the diet.

When the loss of the circulating proteins during a period of 80 days on the diet is expressed as a percentage of the original quantity present, it appears that serum albumin suffers the greatest depletion, that hemoglobin is somewhat less involved, and that serum globulin is very slightly affected. When the loss is considered in terms of absolute quantity of protein removed from the circulation, it is six times as great for hemoglobin as for serum albumin and seven times as great for serum albumin as for serum globulin. When the loss of protein from the circulation is compared with the total loss of protein from the body, it appears that about one-fifth of the total loss is from the circulation and that about four-fifths is from tissues outside the blood stream.

It is pointed out that the depletion of hemoglobin brought about by the diet may not result entirely from a defect in the ability to form hemoglobin but that there may also be a failure to produce the structural material for building red cells. A group of clinical patients is cited in whom the 
results of serial hemoglobin determinations can be interpreted in the light of findings in this investigation. These are patients who are developing or recovering from deficits in serum albumin and in whom the hemoglobin level will be affected by the associated changes in plasma volume.

\section{BIBLIOGRAPHY}

1. Weech, A. A., Goettsch, E., and Reeves, E. B., Nutritional edema in the dog. I. Development of hypoproteinemia on a diet deficient in protein. $\mathrm{J}$. Exper. Med., 1935, 61, 299.

2. Weech, A. A., and Paige, B. H., Nutritional edema in the dog. IV. Peptic ulcer produced by the same low protein diet that leads to hypoproteinemia and edema. Am. J. Path., 1937, 13, 249.

3. Hooper, C. W., Smith, H. P., Belt, A. E., and Whipple, G. H., Blood volume studies. I. Experimental control of a dye blood volume method. Am. J. Physiol., 1920, 51, 205.

4. Gregersen, M. I., Gibson, J. J., and Stead, E. A., Plasma volume determination with dyes: errors in colorimetry; use of the blue dye T-1824. Am. J. Physiol. (Proc.), 1935, 113, 54.

5. Graff, S., and Clarke, H. T., Determination of plasma volume. I. The dye method. Arch. Int. Med., 1931, 48, 808.

6. Darrow, D. C., and Buckman, T. E., The volume of the blood. II. The volume of the blood and concentration of crystalloids and electrolytes in de- hydration and edema. Am. J. Dis. Child., 1928, $36,248$.

7. Chang, H. C., Plasma protein and blood volume. Proc. Soc. Exper. Biol. and Med., 1932, 29, 829.

8. Lepore, M. J., Relation of plasma volume to plasma protein concentration. Proc. Soc. Exper. Biol. and Med., 1932, 30, 268.

9. Weech, A. A., Goettsch, E., and Reeves, E. B., The effect of serum transfusion on the plasma protein depletion associated with nutritional edema in dogs. J. Clin. Invest., 1933, 12, 217.

10. Melnick, D., and Cowgill, G. R., The serum protein complex as a factor in regulating blood volume. Proc. Soc. Exper. Biol. and Med., 1936, 35, 312.

11. Whipple, G. H., and Robscheit-Robbins, F. S., Blood regeneration in severe anemia. I. Standard basal ration, bread and experimental methods. Am. J. Physiol., 1925, 72, 395.

Robscheit-Robbins, F. S., and Whipple, G. H., Reserve store of hemoglobin producing substances in growing dogs as influenced by diet. Am. J. Physiol., 1935, 112, 27.

12. Addis, T.. Poo, L. J., and Lew, W., The quantities of protein lost by the various organs and tissues of the body during a fast. J. Biol. Chem., 1936, 115, 111.

13. Cooley, T. B., In discussion following paper by Weech, A. A., Wollstein, M., and Goettsch, E., Dietary protein and hemoglobin formation: an experimental study. Am. J. Dis. Child. (Proc.), 1936, 52, 1282. 